\title{
高重合度ポリアクリロニトリル中空糸膜モジュール
}

\author{
栗 原優
}

東レ株式会社 高分子研究所

\section{High Molecular Weight Polyacrylonitrile Hollow Fiber Membrane Modules}

\section{Masaru KURIHARA}

Toray Industry, Inc. Polymers Research Labs.

\begin{abstract}
An ultrafiltration membrane, prepared from specially polymerized polyacrylonitrile with high molecular weight, has been developed by Toray Industries, Inc. This new membrane and its modules are designed specially for reducing membrane fouling.
\end{abstract}

Key words : polyacrylonitrile, hollow fiber membrane, membrane cleaning

\section{1. はじめに}

近年, いわゆるおいしい水, きれいな水への要望が高ま り始めている中で, 膜分離技術を除濁用途に展開してい こうとする動きが見られ始めている．従来，膜分離技術 は一般に，逆浸透膜や限外万過膜などを用いたいわゆる 機能性を重視する分離用途を中心として大きく展開され てきた. しかし最近になって, 北千葉取水場で行われて いる膜利用型水道浄水システム開発研究 (MAC-21 計 画）や横須賀市水道局で行われている次世代型高品位浄 水プロセス実験などを始めとして, 従来は砂ろ過やカー トリッジ式フィルターなどで処理されることが多かった 工業用水や河川水などの除濁用途に, 膜分離技術を適用

\section{しょうとする活発な検討が開始されている.}

工業用水のろ過や河川水の浄化などの一般除濁用途で は，必要十分なろ過性能と長期に渡り安心して使用でき る耐久性が重要である．東レ株式会社では，高重合度の ポリアクリロニトリル (PAN) を素材とした除濁用中空 糸膜モジュールを開発し市場展開を開始したので，その 概要を紹介する.

\section{2. 膜素材と膜形態}

PAN はろ過素材として長年の実績があるが，一般除 濁用途においては繰り返しの洗浄操作が必要であり, そ の機械的強度は十分とは言い難い面があった. 東レでは, 通常市販のものに比べて約 3 倍の重合度を有したPAN ポリマーを使用することで，機械的強度に優れた中空糸 膜を製膜することに成功した. 除濁用中空糸膜としては, 中空糸膜の外表面の緻密層が出来るだけ薄い非対称構造 が好ましく，このような形態の中空系膜を乾湿式製膜法 で製膜する技術を確立した（Fig. 1)，すなわち，中空 糸膜外表面の緻密層の孔径を, 限外万過と精密ろ過領域 の中間である $0.01 \mu \mathrm{m}$ 程度に設定することで，優れた ろ過性能と耐污れ性を両立することができた．また，外 表面から内表面に向かうにつれての孔径が大きくなるよ うに非対称構造を設計し，万過抵抗を少なくした。ささら に, 本中空糸膜は, 内径 $350 \mu \mathrm{m}$, 外径 $450 \mu \mathrm{m}$ 程度と し, 実用領域における, 中空糸膜内部の圧力損失の影響 が小さくなるように設計している. 


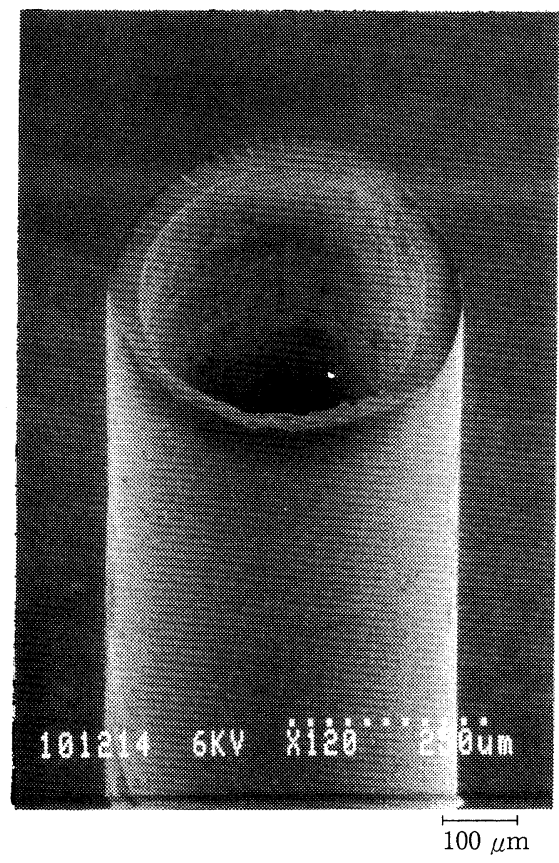

全体像

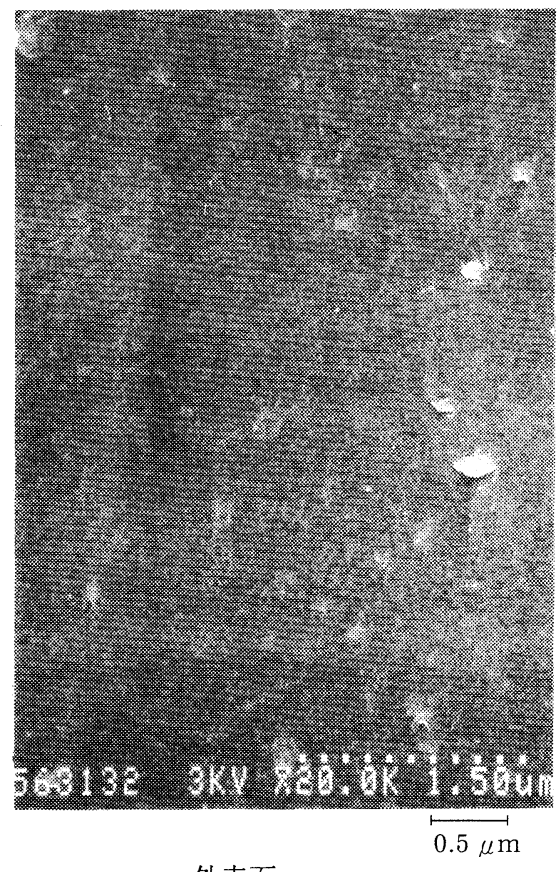

外表面
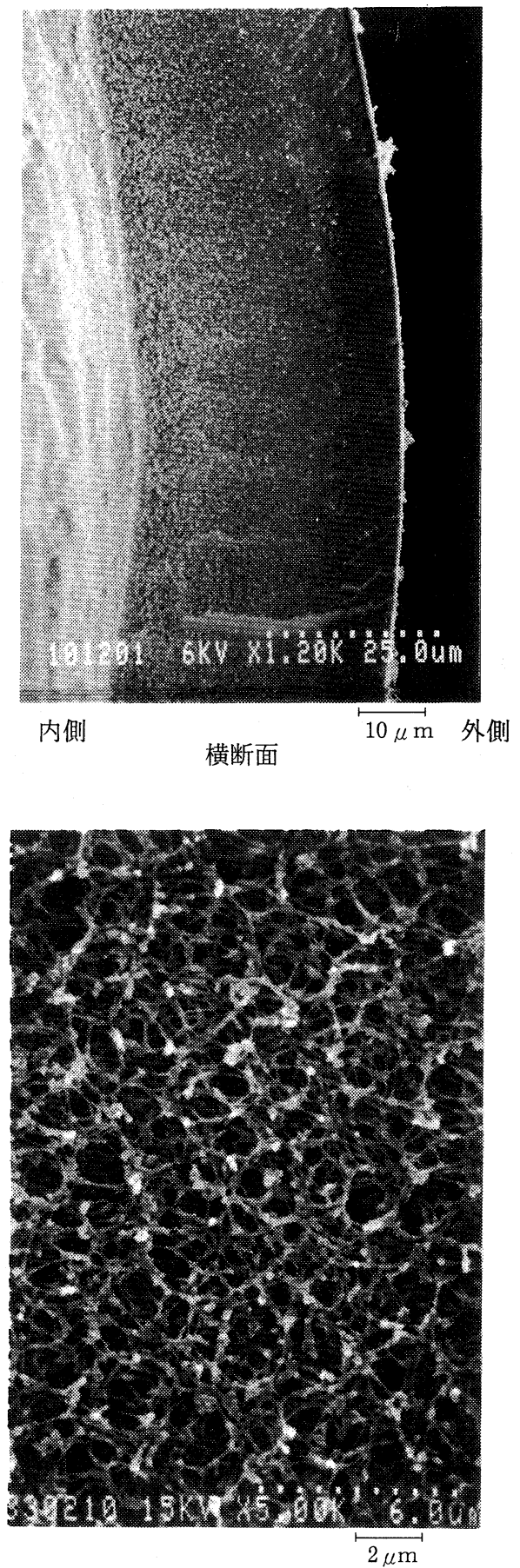

内表面

Fig. 1 FE-SEM photograph of hollow fiber membrane (中空糸膜の FE-SEM 顕微鏡写真) 


\section{3. モジュール}

中空糸膜モジュールは, 直径約 $10 \mathrm{~cm}$, 長さ約 $100 \mathrm{~cm}$ 程度のプラスチック容器に組み込まれた形状であり, 多 穴中心パイプに回りに約 10,000 本 (膜面積約 $12 \mathrm{~m}^{2}$ ) の中空糸膜を配列し膜束の両端を接着剤で固定している (Fig. 2). 中空糸膜モジュールは通常縦置きに設置し て, 原水を中空糸膜の外側加供給する外圧全ろ過型で 使用し, 膜の污れに応じてエアースクラビングによる膜 の物理洗浄が行われる. 膜の物理洗浄は, 膜の性能を回 復させるために定期または不定期に行う。エアースクラ ビングは, 中空糸膜束の中央部に設けられた多穴中心パ イプから膜束内部にエアーを供給し, 中空糸膜を摇り動 かして膜表面を互いに擦りあわせることにより膜面の付

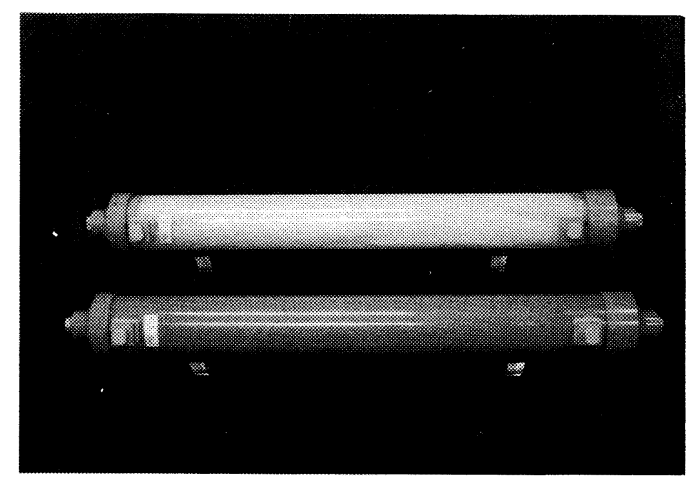

Fig. 2 Outside shape of hollow fiber membrane module （中空糸膜モジュール外観）
着污れを除去する. エアースクラビング物理洗浄の繰り 返しにより中空糸膜の切損や膜表面の磨耗などが懸念さ れたが, 高重合度ポリマーを使用したPAN 中空糸膜で は, 約 20,000 回のエアースクラビング操作の繰り返し によっても中空糸膜の切損や表面の磨耗などは見られな かった.

\section{4. 万過性能}

中空糸膜の表面ポアサイズは $0.01 \mu \mathrm{m}$ と小さいため に, ろ過水の清純度は微粒子数で数個 / $\mathrm{cc}$ 以下と非常 に高いレベルにある.この膜モジュールの特徴は, 目詰 まりしにくい膜の特徴を生かした優れた物理洗浄回復性 にある. 運転条件および物理洗浄条件は処理原水の水 質, 水温, ろ過流束, 圧力, 薬品注入の有無などによっ て異なるために条件の最適化設定が必要であるが，河川 表流水による凝集剂無添加系においては, 通常ろ過速度 $0.02 \sim 0.05 \mathrm{~m} / \mathrm{h}$, 物理洗浄周期 60 120 分, エアースク ラビング洗浄時間 5〜10 分/回程度に設定する.

Fig. 3 は, 膜面積 $12 \mathrm{~m}^{2}$ の中空糸膜モジュールを用 いて, 東レ(株) 滋賀工場の工業用水を原水として 1 年 間の実証運転を行った結果である. 原水は, 琵琶湖水を 砂乃過処理した後, 数百 $\mathrm{m}$ 程度の老朽配管で送水されて いる濁度 1 程度の水であり, 鉄系の濁質が多く含まれて いる. 運転条件は, 万過速度 $1.2 \mathrm{~m} /$ 日の全ろ過方式と し, 凝集剤は添加せず, ろ過差圧の自動調整によってろ 過流量が一定になるように運転している，また，ろ過差 圧が $1.2 \mathrm{kgf} / \mathrm{m}^{2}$ 程度にまで上昇した時点を目安とし て，エアースクラビングによる物理洗浄を行った. 季節

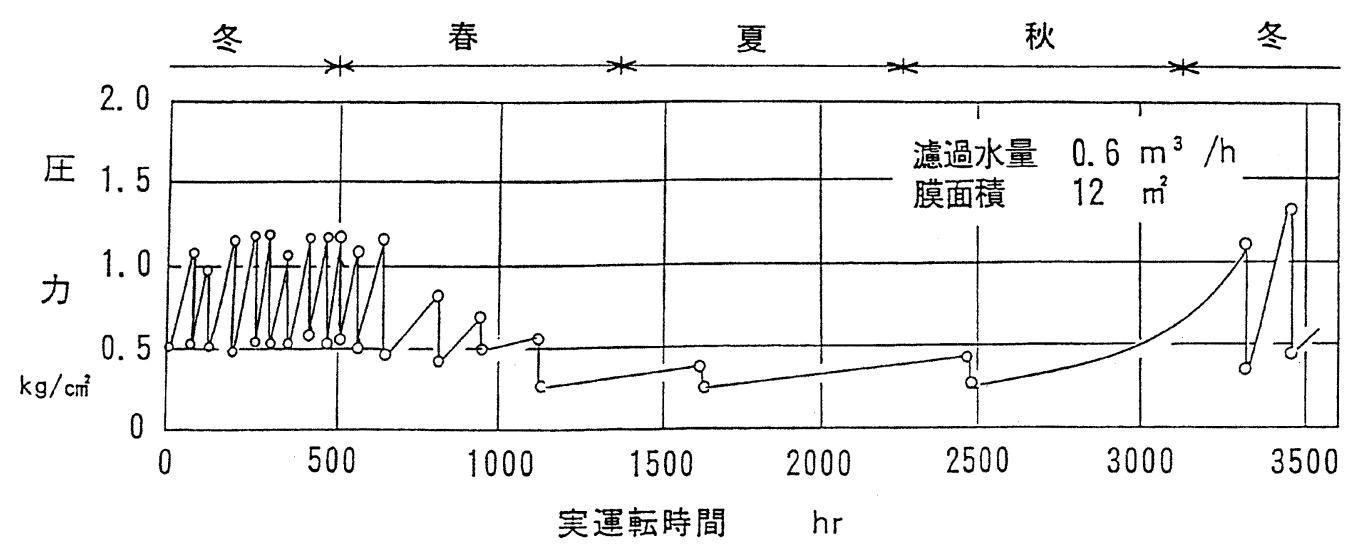

Fig. 3 One year operation data of polyacrylonitrile hollow fiber membrane module （ポリアクリロニトリル中空糸膜モジュール, 1 年間の運転実証例） 
によりろ過差圧の上昇傾向が見られているが， 1 年間経 過した時点においても良好なろ過性能が保持されている ことが実証された.

\section{5.おわりに}

高重合度 PAN 中空糸膜モジュールの実用性について は, 琵琶湖水, 工業用水などを使用した社内実績データー
の蓄積を重ねており, 今年度からは社外への求評活動を 開始している，膜を用いた除濁プロセスのメリットとし ては, 装置の小型化, 水質の高位安定性, 維持管理の簡 略化などがあげられる，膜の適用用途としては，工業用 水や河川水の浄化用途を始め, ビルの赤水ラインの鉄錆 除去, 逆浸透膜の前処理用途などが期待されており, 今 後ともさらに技術改良, 用途展開などを進めていきたい.

（受付 1993 年 6 月 12 日） 